\title{
Construction Meaning "Wages and Protest " in the Context of Tripartite over Bandung, West Java ( Case Study of Tripartite Perspective in Bandung Raya)
}

\author{
Suwandi Sumartias \\ Faculty of Comunication Sciences \\ Universitas Padjadjaran Bandung \\ suwandi.sumartias@unpad.ac.id \\ Dede Mariana \\ Faculty of Political and Social Sciences \\ Universitas Padjadjaran Bandung \\ dedemariana@yahoo.com
}

\begin{abstract}
Research purpose to elaborate on the meaning of "wages and protests" among workers, employers and government (Tripartite). By early 2017, the workers demonstrated against the Government Regulation No. 78/2015 about wages was considered incompatible with the aspirations of the workers in life worthy. In Bandung, West Java, thousands of workers took to the streets against the minimum wage City/district set West Java provincial government on minimum wage fixing Year 2017 in Decree No. 561/Kep.1191-Bangsos/2016. The method used a case study with qualitative paradigm. The results showed that that wages as an essential element for survival on the job still considered the workers are still far away from the needs of daily life worth living. The Employers and government considered the wages are set through regulations has met the standards of daily life worth living. the workers felt excluded in determining a fair wage. The protest is considered the workers to be the strategy of their fate, because the dialogue or communication between employers and workers often do not solve the problem. Protest been able pressing employers and governments to concerned about their fate. Politicization protest often used by labor activists to express their aspirations. While, employers feel that the protest made a great disadvantage for companies, led to the cessation of production. The protest is a form of the workers resistance are always positioned by governments and employers as part of the "outside" company. Also be a picture of the failure of communication and negotiation at the level bipartite (employers-workers) and tripartite (employer-labor and government). The tripartite relationship is characterized conflictual and exploitative relationships.
\end{abstract}

\section{Keywords: Construction; Wage; Protests; life worthy; bipartite; tripartite}

\section{INTRODUCTION}

Working relationships between employers and workers in an industry in some regions of Indonesia are still troubled by serious problems. Especially with regard to the issue of wages and labor welfare.

The massive labor protests against the cancellation of Government Regulation No. 78 of 2015 on remuneration became one indicator of the lives of workers who are still not prosperous.

On the other hand, the role of the government as a facilitator and regulator in determining the minimum wage of workers is still considered by the workers not to be optimal in fighting for the basic rights of the workers. Even the government seemed not to bother with the protests and let it happen continuously.

Currently the position of the workers in terms of determining the minimum wage feels uninvolved, so the government regulation is considered to perpetuate low wages. Many cases of protests, normative matters, especially the issue of minimum wages, injustice and lack of welfare are often strong grounds for demonstrations or strikes. A wave of protests against government regulations is a form of labor resistance that is always positioned by governments and employers as an "outsider".

The failure of communication and negotiation at the bipartite level (employer-labor) and the weakness of tripartite relations (employers and the government) have been long and classical, even those relationships are more colored by conflictual and exploitative relationships. Labor is always positioned as a weak and marginalized group, not as an essential part of an egalitarian and synergistic production relation for enterprise progress

Bandung as the Capital of West Java Province, often became the center of gathering of workers from various districts / cities in West Java to demonstrate, especially 
from the existing industry in the City / Regency Bandung and Cimahi

Referring to the Central Bureau of Statistics (2016), the number of workers based on main employment in 2016 reached 120,647,697 people, of which working in the industrial sector as many as $15,975,086$ people with the largest contribution from West Java Province about 3,892,044 people (24,93\%), Central Java 3.219.793 people $(20.16 \%)$, and East Java 2,948,203 persons $(18.46 \%$

Related to the problem of decentralization, development, and the achievement of community welfare, West Java Provincial Government (West Java Provincial Government) has Vision and Mission 20132018 "West Java Forward and Prosperous For All".

Progress as productive, competitive and self-reliant, skilled and innovative society condition while maintaining the social order of society that is tolerant, rational, wise and adaptive to the dynamics of change and adhering to cultural values and local wisdom and sovereign food, economic and social resilience .

Prosperous interpreted as a condition of society that inwardly and inner get a sense of security and prosper in the life. While For All means conditions where the results of development can be felt by all layers, elements and components of society.

The performance of West Java provincial government in realizing the prosperity of society and local democracy, one of them is measured from indicator of achievement of HDI (Human Development Index). West Java HDI in 2014 reached 74.28, an increase compared to previous years. In addition to HDI, West Java in 2013 is rated as a province that experienced an increase in democratic index from 57.05 in 2012 to 65.18 in 2013, although the West Java democracy index is still well below the national index of democracy average of 77.94 . Assessment of democracy index refers to three aspects, namely the aspect of civil liberties, aspects of political rights fulfillment, and aspects of democratic institutions.

While the poverty rate of the people of West Java, from year to year decreased. The West Java population poverty rate in 2013 was 9.52 percent (BPS, 2013), and in 2014 fell to 9.44 percent, below the national poverty rate of 11.37 percent. The National Development Planning Agency report (2014) also points out that the open unemployment rate in West Java is generally higher than the national average. In addition, West Java is the area with the highest number of trafficking victims, especially children and women in Indonesia, indicating the low level of protection for both vulnerable groups.

Other West Java issues or challenges related to the strategic role of industrial relations actors (entrepreneurs, government and workers) in the context of development, in particular to build a dialogical, harmonious and open communication model in order to achieve sustainable and prosperous industrial relations (tripartite) in the era of democratization. Often the communication between actors in production relations is disrupted with various interests that are difficult to carry out deliberations. The relatively high frequency of demonstrations by laborers in West Java is a serious indicator of building harmonious relationships among industry actors. Especially because of the issue of minimum wage.

\section{LITERATURE REVIEW}

Minimum Wage is a minimum standard used by employers or industry players to provide wages to workers in the business or work environment.

An industrial relations analyst, Paul Krugman (1997) says that a trader can sell a lot of goods, but a worker usually has only one job, which not only sustains his life but also his identity needs. Unsold goods are only annoying, but an unemployed worker is a tragedy.

It is not easy to understand the labor movement as a pure form of socio-economic struggle and movement. Work lived for many years, still can not meet what the needs of their life, moreover their sense of identity. Of the 1945 Constitution (article 27, paragraph 2) and also Law No. 39 of 1999 on Human Rights, guarantee the right of every citizen to the work and livelihood that is suitable for humanity. The Constitution and the Act have not been able to guarantee all this. Including the birth of government regulations on wages above, they consider not be involved in the determination of wages and perpetuate the politics of cheap wages. Even if workers are active in union activities, wages will not be paid.

On the other hand, the working and living conditions of the workers still have not moved from the normative issues that the workers demand, including the low level of workers' welfare and the low wages of the workers. The lack of skills and the lack of labor productivity becomes an obstacle in the pursuit of a harmonious bipartite relationship.

In contrast, workers perceive that employers often do not have good intentions for the welfare of their workers, and are only pursuing profits. The wages they earn often do not meet the minimum physical needs, while the price of basic necessities on the market continues to increase, while their wages are no longer able to pursue market demands.

Basic calculation of minimum wages of laborers KHL (Decent Living Needs) is regulated in Law no. 13 of 2003 on Employment, the Government establishes the KHL standard as the basis for determining the Minimum Wage as stipulated in article 88 paragraph 4 . The KHL Standard consists of several components: Food \& Beverage (11 items); Clothing (13 items); Housing (26 items); Education (2 items); Health (5 items); Transportation (1 item); Recreation and Savings (2 items), bringing the total wage component to 60 items. Over the 60 items wages earned by the workers, it is often assumed that the workers have not yet fulfilled their proper living needs, so they demand 80 additional items. And in the negotiations on minimum wage determination, workers 
often judge the employer not to take sides with them, and the government is considered to be impartial to the workers, but rather to the employer in the effort to minimize spending on wages.

Communication among employers is often not smooth and hampers company productivity. Production and work relationships are not only seen from the aspects of material benefits, but strengthen simultaneously the sense of pride and appreciation as the actor of the production of work and social relations. (Sumartias, 2012).

In very weak situations and positions of labor in many cases, moreover exacerbated by weak supervision and enforcement of regulations by the relevant agencies, certainly exacerbates the position of laborers in production relations. In some of the more industrialized countries, production relations are purely businessmen and laborers, the government is entirely believed to be a "referee" and a professional and fair facilitator. While the production relations in Indonesia on the contrary, all actors in the production flow still have weaknesses in various matters, including the lack of awareness in carrying out and performing their respective roles and functions.

Even Karl Marx in Sumartias (2015) asserted that the main interest of the bourgeoisie (the owner of capital) is to obtain maximum profit. Conversely, the proletariat (labor) needs more salary, a salary that reduces the employer's profits, and when the employer does not meet the demands of the workers there is an industrial conflict. Conflict develops on the basis of conflict of interest between workers and employers of wages, due to differences of meaning and interests, the conflict arises.

On the other hand, the conflict is dangerous because the conflict itself is dysfunctional, resulting in disunity, and disrupting the community. The interesting solution came from Keisuke Fuse (Director of the International Department of Confederation of Japan's National Workers Union-Zenroren) that the potential for industrial relations conflicts can actually be suppressed if employers and workers can be open to each other in the company. Honesty will build trust and create a calm working in the company. One recipe manages industrial relations conflicts. Management and unions communicate intensively, especially in terms of setting company targets and strategies to win the market, so that all parties have a moral responsibility in work. (Sumartias, 2015).

Talcott Parsons and Edward Shills (1951) in Suparlan (1999) declare that social processes embodied as social actions are essentially aimed at mutual cooperation among actors who are citizens. Social processes have functional functions that emphasize the objectives of social and community life which have a balance or equilibrium pattern among its elements, resulting in social and social integration.

Max Weber in Poloma (1994) tries to understand social action interpretively so as to arrive at a causal explanation of the purpose or meaning of events. For
Weber, the study of "social action" means seeking subjective understanding or motivation related to social actions.

Through the Work, The Protestant Ethic and the Spirit of Capitalism, Weber (1958), discusses the relationship between a rational, Protestant Calvinist movement with rational pursuit of profit (capitalism). Another tendency in the movement toward this rational action is also shown by the birth of bureaucratic organization. In contemporary society, an action is more likely to be rational in achieving goals or goals (organization or leadership) with the most appropriate means (weighted leadership, impersonal organization). The theory of action or action of Parsons is influenced by Durkheim, Marshall and Pareto or Weber which emphasize situational factors that aid individual action.

Ralf Dahrendorf in Garna (1999) reveals that in society life has a social order with certain characteristics: (1) that is in the interest of all individuals in regulating their social order; (2) showing togetherness in carrying out the role of norms and values; (4) emphasizing rules with power and dominance because of their capacity. In the perspective of conflict, every society will: (1) always experience social change; (2) always experience social conflict; (3) depending on the pressure of some members to other members; (4) every element in the society contributes to change.

Then the consensus perspective with the structuralfunctional basis according to Garna (1999) that each society is: (1) the configuration of the rather eternal elements; (2) well-integrated elements; (3) every element in society contributes to the functioning of the whole society; And (4) its existence depends on agreement among community members.

Differentiated division of labor, in Weber's view, according to Giddens (1971) characterizes capitalism. Weber does not reject Marx's argument that modern capitalism results in a class system based on capital and paid work. The class system arising from the division of labor is characterized by bureaucracy as the most integral nuance of modern capitalism.

Weber argues that any form of organization that has hierarchy and authority can be the subject of a decisionmaking process. Weber replaced the "tool of production" in Marx's understanding with the term "administrative tools". Domination and "subordination" instead of "production relations". In Weber's understanding, the more an organization approaches the ideal type of organization, the more it can be called "bureaucratized" (Giddens, 1982).

Then Dunlop (1958) argues, actors in industrial relations include: (1) the hierarchy of managers and their representatives for oversight; (2) the hierarchy of the workers (non-managerials) and their spokespersons, and (3) certain government agencies and certain private agencies established by the two principals concerned with workers, companies and their relations. (Tripartite Pluralism). One of the major problems in the hierarchy 
of actors in this industrial relation, is the difficulty of communication and the true understanding between the experts and the other of the hierarchy.

Conflict is a process that occurs when a person's behavior is hampered because of the behavior of others. Conflict often occurs in close relationships (Peterson, 1983). Conflict will more easily arise when interdependence increases. As the interaction becomes more frequent and involves a wide range of activities and matters, the chances for a mismatch will be greater (Sears, 1985).

Marx and Engels in Garna (1992) put forward two main postulates, the first of which is economic determinism which states economic factors are fundamental determinants of structure and change of society, technological forms of production determine the social organization of production, Produce results more effectively. Second, to touch the mechanism of change, which, according to Marx's view, social change must be understood in the sense of three phases or stages which always appear. The three stages are a dialectical scheme of Georg Hegel.

Dahrendorf in Ritzer and Goodman (2005) says that every society is at all times subject to the process of change. Disputes and conflicts occur within the social system. Various elements of society contribute to disintegration and change. Conflict theorists see whatever order in society comes from coercion of its members by those above. Theoretical conflict emphasizes the role of power in maintaining order in society. Society has two faces (conflict and consensus).

Robbins (1996) says there are three views on conflict: The traditional view of conflict, which believes that conflicts are harmful and should be avoided; (2) human relations view of conflict, which believes that conflict is a natural and inevitable result in every group; And (3) the interactionist view of conflict, which believes that conflict is not only a positive force within a group but also absolutely necessary for a group to perform effectively.

Hebert Blumer (1939): Social movements can be viewed as collective enterprises to establish a new order of life. They have their inception in the condition of unrest, and derive their motive power on one hand from dissatisfaction with the current form of life, and on the other hand, from wishes and hopes for a new scheme or system of living.

Turner and Killan (1987) in Muukkonen (1999), social movement is a collectivity acting with some continuity to promote or resist a change in the society or groups of which it is a part. McCarthy and Zald (1977) dalam Muukkonen (1999), social movement is a set of opinions and belief in a population which represent preferences for changing some elements of the social structure and for reward distribution of society. Anthony Giddens (2001), social movement is "a large grouping of people who have become involved in seeking to accomplish, or to block, a process of social change.
Social movements normaly exist in relations of conflict with organizations whose abjectives and outlook they frequently oppose. However, movements which successfully challenge for power, once they become institutionalized, can develop into organizations.

John Dunlop (1958): for a certain time such industrial relationship system will be regarded as an ideology representing the system of certain practitioner, and for a certain context the same way happened to the regulations controlling the workers in the workplace and in the working community.

\section{III.Method}

The study used a qualitative approach with case studies, so that this research can find the uniqueness and attractiveness such as: characteristic / nature of the case, its historical background, context / setting physical, other contexts include economic, political, legal, aesthetic, other cases are relate so that these cases can be identified, as well as informants to identify the source case. Key Informant: Labors; Employers dan Government officer in Bandung Raya as well as related of Wages and Protest . Data were collected through interviews, observation and document tracking. This type of research is descriptive research that aims to explain the precise properties of the individual, the state, the symptoms of a particular group.

This research examine and elaborate the understanding of the workers; employers and government officer over wages and protests in Bandung. To maintain the validity, triangulation of data, creating a rich and dense description, clarified researcher bias that may be brought into the study

\section{Result}

\section{Meaning of Wages}

Referring to the Central Bureau of Statistics (2017), the number of manpower based on main employment in 2016 reached 120,647,697 people, of which 15,975,086 people work in industry sector with the largest contribution from West Java Province about 3,892,044 people ( $24.93 \%)$, Central Java 3.219 .793 people (20.16\%), and East Java 2,948,203 people (18.46\%). 
Table 1: Decision of the West Java Governor No. 561 / Kep. 1191-Bangsos / 2016 dated 21 November 2016 regarding Regency/Municipality Minimum Wage in West Java in 2017

\begin{tabular}{|c|c|c|}
\hline No & Regency/City & Minimum Wages 2017 \\
\hline 1 & $\begin{array}{l}\text { Kabupaten } \\
\text { Majalengka }\end{array}$ & Rp1.525.632,00 \\
\hline 2 & Kota Cirebon & Rp1.741.682,96 \\
\hline 3 & Kabupaten Cirebon & Rp1.723.578,15 \\
\hline 4 & Kabupaten Kuningan & Rp1.477.352,70 \\
\hline 5 & Kabupaten Indramayu & Rp1.803.239,33 \\
\hline 6 & Kabupaten Garut & Rp1.538.909,00 \\
\hline 7 & $\begin{array}{l}\text { Kabupaten } \\
\text { Tasikmalaya }\end{array}$ & Rp1.767.029,70 \\
\hline 8 & Kota Tasikmalaya & Rp1.776.686,00 \\
\hline 9 & Kabupaten Ciamis & Rp1.475.792,82 \\
\hline 10 & Kota Banjar & Rp1.437.522,11 \\
\hline 11 & $\begin{array}{l}\text { Kabupaten } \\
\text { Pangandaran }\end{array}$ & Rp1.433.901,15 \\
\hline 12 & Kota Depok & Rp3.297.489,00 \\
\hline 13 & Kabupaten Bogor & Rp3.204.551,81 \\
\hline 14 & Kota Bogor & Rp3.272.143,00 \\
\hline 15 & Kabupaten Sukabumi & Rp2.376.558,39 \\
\hline 16 & Kota Sukabumi & Rp1.985.494,00 \\
\hline 17 & Kabupaten Cianjur & Rp1.989.115,00 \\
\hline 18 & Kota Bandung & Rp2.843.662,55 \\
\hline 19 & Kabupaten Bandung & Rp2.463.461,49 \\
\hline 20 & $\begin{array}{l}\text { Kabupaten Bandung } \\
\text { Barat }\end{array}$ & Rp2.468.289,44 \\
\hline 21 & Kabupaten Sumedang & Rp2.463.461,49 \\
\hline 22 & Kota Cimahi & Rp2.463.461,00 \\
\hline 23 & Kota Bekasi & Rp3.601.650,00 \\
\hline 24 & Kabupaten Bekasi & Rp3.530.438,44 \\
\hline 25 & Kabupaten Karawang & Rp3.605.272,00 \\
\hline 26 & Kabupaten Purwakarta & Rp3.169.549,17 \\
\hline 27 & Kabupaten Subang & Rp2.327.072,00 \\
\hline
\end{tabular}

The table of minimum wages, still become the problem among the workers and far from their daily decent life. While entrepreneurs and the government think it has been optimal to do their duty to make workers prosperous. Even many entrepreneurs are applying for delaying of the minimum wages.

Minimum wages structure in West Java is interpreted very positively by Ade Sudrajat as Chairman of Indonesian Textile Association, as quoted by British Broadcasting Corporation (BBC) Indonesia (2015) as a visionary regulation and provide clarity for the business world, so that investors do not hesitate to embed Capital in Indonesia, especially in Bandung West Java

Providing certainty fot the entrepreneurs, as well as the existence of transparency to buyers of Indonesian products abroad to know for sure whether the price they pay in accordance with the components of production costs. We are not faced with a conflicting situation that we must kill with workers, we are partners, that is important. If the workers demanded by protest with a $40 \%$ minimum wage increase, it certainly would not provide socioeconomic stability.

The opinion of the entrepreneur above has the support of Sjukur Sarto, President of the All-Indonesia Trade Union Confederation (KSPSI), that the minimum wage regulation of the government can minimize the potential for conflict between employers and workers. The basic minimum wage calculation without survey, is a simpler formula. During this time always the survey results make a tough debate between employers and workers

Minister of Manpower Hanif Dhakiri (2016) said that this wage increase will ensure business certainty and investment for entrepreneurs in order to predict an increase in production costs

However, Secretary-General KSPI Muhammad Rusdi (2016) said that the government regulation on wages does not address the needs of the workers, but only responds to the wishes of the entrepreneur. The formula for the increase in wage labor announced by the government will not be able to approach the standard of decent living needs.

In the determining minimum wages of private and government, workers and informal workers, it has long been in a state that no longer represents a sovereign and dignified country, both in national, regional and international contexts. The state-determined wage structure or salary becomes one of the key and important indicators for measuring the per capita income level of its citizens, which is closely related to the level of citizens' welfare. 
Table 2: Over the Asean regional sphere, Indonesians rank at 130, with per capita income of 11,200 US dollars.

\begin{tabular}{|c|c|c|c|c|}
\hline $\begin{array}{l}\text { Ranking } \\
\text { in } \\
\text { Asean }\end{array}$ & State & $\begin{array}{l}\text { Per } \\
\text { Capita } \\
\text { GDP } \\
\text { (USD) }\end{array}$ & $\begin{array}{l}\text { Ranking } \\
\text { world }\end{array}$ & Population \\
\hline 15 & $\begin{array}{l}\text { Papua } \\
\text { Nugini }\end{array}$ & 3.500 & 184 & 6.791 .317 \\
\hline 14 & Kamboja & 3.700 & 180 & 15.957 .223 \\
\hline 13 & Bangladesh & 3.900 & 177 & 156.186 .882 \\
\hline 12 & Timor Leste & 4.200 & 176 & 1.261 .072 \\
\hline 11 & Laos & 5.700 & 165 & 7.019 .073 \\
\hline 10 & $\begin{array}{c}\text { Myanmar } \\
\text { (Burma) }\end{array}$ & 6.000 & 162 & 56.890 .418 \\
\hline 9 & Vietnam & 6.400 & 161 & 95.261 .021 \\
\hline 8 & Filipina & 7.700 & 154 & 102.624 .209 \\
\hline 7 & Indonesia & 11.700 & 130 & 258.316 .051 \\
\hline 6 & $\begin{array}{c}\text { Palau } \\
\text { Belau) }\end{array}$ & 15.300 & 105 & 21.347 \\
\hline 5 & Thailand & 16.800 & 100 & 68.200 .824 \\
\hline 4 & Malaysia & 27.200 & 70 & 30.949 .962 \\
\hline 3 & Taiwan & 47.800 & 30 & 23.464 .787 \\
\hline 2 & $\begin{array}{c}\text { Brunei } \\
\text { Darussalam }\end{array}$ & 79.700 & 8 & 436.620 \\
\hline 1 & Singapura & 87.100 & 5 & 5.781 .728 \\
\hline
\end{tabular}

Through the table 2 , it is generally still relatively 'safe' in terms of rank, given the vast and vast population and large population. But on the other hand, the level of welfare of citizens and other issues, should still be scrutinized and criticized. This becomes important, because the advanced and prosperous country is the hope of all citizens. Especially with adjacent countries, al. Singapore and Malaysia, the batapa (government) state has the seriousness of managing the country and its citizens, at least, their per capita income level, far beyond Indonesia. Minimum wage and or salary standard for its citizens, really get serious attention.

Labor reseacher, Rosyidah (2015), saw a protest about wages being a common thing, we are still more aligned to the market than the workers. With very minimal wages over the years, The life's workers is far from worthy living. We are concerned with the workers, but to make a decent living is very impartial.

Chairman of the All Indonesian Workers Union (SPSI) West Java Roy Jinto (2016) said we will be accounted the decision of the Governor of West Java related to the determination of Province Minimum Wage (UMP) 2017 to the State Administrative Court (PTUN)

Accenture (2016), a United States business and management consulting firm, released their latest study on March 8, 2016. The study, which examines employee satisfaction rates, showed that only 18 percent of the worker group in Indonesia said they were satisfied with the quality of life and His happiness at work. The three most commonly complained issues are the balance between work and personal life, the amount of salary and benefits, and the availability of career paths.
Federation of Trade Unions (2017) Said: Minimum Wage is not up to date, the People Need Real Wage, Social Security Administering Body (BPJS) Should Be Engaged by Indonesian Workers. The government is asked to maximize the social security program for the fulfillment of real wages of Indonesian workers.

Secretary General of Indonesian Workers' Organization (OPSI) Timboel Siregar (2017) said that the wages rules in Indonesia are still very vulnerable with only the number of numbers that are not able to boost the welfare of workers 's life. This is due to the low level of government concern for workers' lives. If the government has a healthy political will to improve the standard of living of the people of Indonesia (especially workers), the government can use Social Security instruments to realize real wages of workers. The social security must be enforced maximally.

\section{The Meaning of Protests}

The worker"s interpretation of the protests, according to research by Sumartias (2009), shows that protests are a struggle for the worker's normative rights. Labor is a particular social community with disadvantaged labels, marginalized socially, economically, culturally and even politically.

In the working relationship, especially workers in Bandung, that the labor relations with the owners of capital (entrepreneurs) still do not give priority to the values of humanity to be able to live decent, ensuring family life, a better future, and can enjoy the work with Full of satisfaction, comfort and hope.

It was found that employers are constantly pressuring permanent workers to become contract workers or freelancers, so that the concerns, discomforts and ambiguities of assurance and certainty of work are increasingly felt by workers

The workers realized that the protest was the ultimate weapon. Protests are not the primary or best way to fight for their demands. It is as the ultimate weapon for unions.

Protests are also a characteristic of trade unions and more oriented political interests. Protests for some unions is not the only way, because it is not necessarily a guarantee for changes in the fate of workers. For us, the rally was the last weapon. There should be negotiations first. If the protests are not used for harming, the production process stops. Usually the demonstration is able to accomplish the fulfillment of aspirations, but sometimes the demonstration is also not considered

The workers also consider that the demonstration is full of differences of interest. Protests are actually important, but workers, better looking for safe in work, and thinking of themselves to keep working is hard enough; Even at the corporate level, workers who protests can be blacklisted. Prostests have not been guaranteed to change worker's lives better. It's as a form of union friend's support from other companies 
(solidarity). Although there is no guarantee of success. Even found the workers who paid for the rally.

\section{Conclusion}

Labor life is still felt far from worthy and prosperity, injustice and exploitation of labor by entrepreneurs is still very massive occurred in various industries in Bandung West Java. The government has not been able to give serious attention in ensuring the life of decent and prosperous workers. Workers recognize that demonstrations are important and characterize trade unions or workers in the struggle for aspirations for a better change of destiny. Research recommendations, honest and open social partnerships and communications between employers and workers are essential to building a harmonious and conducive working relationship.

\section{Reference}

Badan Pusat Statistik Indonesia, (2013; 2015 dan 2016).

Coser, Lewis A. 1956. The Functions of Social Conflict. New York : The Free Press.

1967. The Study of Social Conflict, The Free Press, New York.

1967. Continuittes in the Studyof Social Conflict.

New York : The Free Press.

1968. "Conflict: Social Aspects". InternationalEncyclopedia of Social

Sciences, David L. Sills (ed), The Macmillan Company \&

The Free Free Press.

. 1970. Men of Ideas : A Sociology's View. New York : The Free Pres.

.1975. The Idea Of Social Structure. New York :

Harcourt Brace Jovanovich, Inc. . 1975a. "Structure and Conflict". Dalam Peter M. Blau (ED.), Approaches to the Study of Social Structure. New York : The Free Press.

1975b. Two Metoas in Search of a Subsstance. American Sociological Review.

\& Bernard Rosenberg. 1976. Structure and Function. New York : Macmillan Publishing Co.,Inc. \& Bernard Rosenberg 1976. Sociological Theory :

A Book of Readings. Edisi Keempat. New York : Macmillan Publishing Co., Inc.

1977. Master of Sociological Thought. 2nd ed. New York : Harcourt Brace Jovanovich, Inc.

Dahrendorf, Ralf. 1959. Class and Class Conflict in Industrial Society. Stanford University Press, California. 1968. Easy in the Theory of Society. Standorf, Calif. : Standorf University Press.

1986. Konflik dan konflik dalam masyarakat Industri, Sebuah Analisa Kritik. (terjemahan), Penerbit Cv. Rajawali, Jakarta.

Departemen Tenaga Kerja R.I. 1974. Keputusan Seminar Hubungan Perburuhan Pancasila. Diterbitkan oleh Depnaker.

. 1987. Reproduksi Peraturan Perundang-undangan

di Bidang Ketenagakerjaan. Diterbitkan oleh Proyek
Peningkatan Pengawasan Norma Ketenagakerjaan Pusat.

. 1990. Himpunan Peraturan Perundang-undangan Bidang Persyaratan Kerja. Jakarta.

Donlop, John T. 1958. Industrial Relation System. Illincis : Southern California Univ. Press.

Durkheim Emile. 1933. The Division of Labor in Society. The Free Press, New York.

Evers, Hans-Dieter 1980. "Ethnic and Class Conflivt in Urban South East Asia". Dalam Sociology in South East Asia. Hans-Dieter-evers (ed), Oxfoid Univesity Press.

1980. "Group Conflict and Class Formation in South East Asia", dalam Sociology in South East Asia, Reading on Social Chanbe and Development. Oxford University Press.

Hyman, Richad. 2000. "Industrial Relations." Dalam Ensiklopedi Ilmu-Ilmu Sosial. Adam Kuper dan Jessica Kuper. PT. RajaGrafindo Persada Jakarta. 1989. The Plotical Economy of Industrial Relations. London.

Johnson, Doyle Pauk. 1981. Sociological Theory. Clasical Founders and Contemporary Perpective. John Wiley \& Sons.Florida.

Krugman, Paul. 1997. In Praise of Cheap Labor. Bad jobs at bad wages are better than no jobs at all. Article. The Search For Better Economic Policy, Maret 21, 1997

Marsh A.I. dan E.O. Evans. 1975. The Dictionary of Industrial Relations. Hutehinson Educational Lth., London.

Neumann, Laurence W. 2002. Social Research Method; Qualitatitve and Quantitative Approach, Thrid Ediition.Wincounsin, Allyn and Bacon, Aviacom Company

Poloma, Margaret M. 1994. Sosiologi Kontemporer. PT. Raja Grafindo. Jakarta

Ritzer, George. 1985. Sosiologi Ilmu Pengetahuan Berparadigma Ganda. Terjemahan Aliman. Rajawali Press. Jakarta

Robbins, S.P. 1996. Organizational Behavior. New Jersey: Prentice Hall International, Inc.

Salamon, Michael.1987. Industrial Relations, Theory and Practice. Prentice-hall New York, London.

Sills, Davis. 1968. "Division of Labour"dalam Internasional Encyclopedia of Social Scien The McMillan Company and the Free Press.

Stake, R. E. 2009.Handbook of Qualitative Research. PustakaPelajar.

Susetiawan. 2000. Konflik Sosial Kajian Sosiologis Hubungan Buruh, Perusahaan Negara Di Indonesia. Pustaka Yogyakarta.

Sumartias, Suwandi (2009). Kontruksi Sosial Buruh Dalam Hubungan Industrial dan Public Relations. Disertasi. Unpad 2012. Reposisi Gerakan Buruh. Artikel. Pikiran Rakyat. 1 Mei 2012. Bandung .2012. Konflik Industrial. Artikel. Pikiran Rakyat. 26 November 2012. Bandung ------. 2015. Buruh dalam Pusaran Konflik. Artikel. Kompas. 1 Desember 2015. Jakarta 
2015. Gerakan Buruh dan MEA 2015, Artikel.

Pikiran Rakyat. 29 April 2015. Bandung.

Sudrajat, Ade. (2015) www.bbc.com/indonesia 